\title{
Pengaruh penggunaan aplikasi PlantNet dan gaya belajar terhadap hasil belajar
}

\author{
Anton Adhy Pujianto ${ }^{1 *}$, I Nyoman Sudana Degeng ${ }^{2}$, Sugito Sugito ${ }^{1}$ \\ ${ }^{1}$ Pascasarjana, Universitas PGRI Adi Buana. \\ Jalan Ngagel Dadi III No. 3B/37, Menanggal, Gayungan, Surabaya, Jawa Timur 60234, Indonesia. \\ ${ }^{2}$ Fakultas Ilmu Pendidikan, Universitas Negeri Malang. \\ Jalan Semarang No. 5, Lowokwaru, Malang, Jawa Timur 65145, Indonesia. \\ antonceow@yahoo.com \\ * Corresponding Author
}

\section{ARTICLE INFO}

\section{Article History}

Received:

25 April 2020;

Revised:

27 May 2020;

Accepted:

15 June 2020

\section{Keywords}

Aplikasi PlantNet;

Gaya belajar;

Hasil belajar;

PlantNet application;

Learning style;

Learning outcomes

\begin{abstract}
Tujuan dari penelitian ini adalah: 1.) Untuk mengetahui pengaruh penggunaan aplikasi PlantNet terhadap hasil belajar; 2.) Untuk mengetahui pengaruh gaya belajar terhadap hasil belajar; dan 3.) Untuk mengetahui interaksi antara penggunaan aplikasi PlantNet dan gaya belajar terhadap hasil belajar IPA siswa kelas VII. Metode penelitian ini menggunakan penelitian eksperimen. Penelitian dilaksanakan pada tanggal 20 Januari 2020 sampai dengan 14 Maret 2020. Populasi dalam penelitian ini sebanyak 32 kelas dengan jumlah sebanyak 1.088 siswa kelas VII ditiga sekolah yaitu SMP Negeri 2 Gedangan, SMP Negeri 3 Sidoarjo, dan SMP Negeri 4 Sidoarjo. Teknik pengambilan sampel penelitian menggunakan simple random sampling, pengambilan sampel secara acak sederhana melalui nomor undian. Dalam pengambilan sampel didapat 3 kelas eksperimen penggunaan aplikasi PlantNet dan 3 kelas kontrol tanpa aplikasi PlantNet menggunakan diskusi kelas. Teknik analisis data menggunakan Anava dua jalur dengan nilai signifikansi sebesar $\alpha=0,05$. Hasil penelitian ini menunjukkan bahwa: 1.) Ada-nya pengaruh penggunaan aplikasi PlantNet terhadap hasil belajar IPA siswa kelas 7; 2.) Adanya pengaruh gaya belajar terhadap hasil belajar IPA siswa kelas 7; dan 3.) Adanya interaksi antara penggunaan aplikasi PlantNet dan gaya belajar terhadap hasil belajar IPA siswa kelas VII.
\end{abstract}

The objectives of this study are: 1.) To determine the effect of using the PlantNet application on learning outcomes; 2.) To determine the effect of learning styles on learning outcomes; and 3.) To determine the interaction between the use of the PlantNet application and learning styles on the learning outcomes of 7 th grade science students. This research method uses experimental research. The study was conducted on January 20 until March 14, 2020. The population in this study was 32 classes with a total of 1,088 7th grade students in three schools, namely SMP Negeri 2 Gedangan, SMP Negeri 3 Sidoarjo, and SMP Negeri 4 Sidoarjo. The research sampling technique uses simple random sampling, simple random sampling through lottery numbers. In sampling obtained 3 experimental classes using the PlantNet application and 3 control classes without the PlantNet application using class discussion. Data analysis technique used two-way Anava with a significance value of $\alpha=0.05$. The results of this study indicate that: 1.) The influence of the use of the PlantNet application on the learning outcomes of the 7 th grade science students; 2.) The influence of learning styles on the results of science learning for 7 th grade students; and 3.) There is an interaction between the use of the PlantNet application and learning styles on the learning outcomes of 7 th grade science students.

This is an open access article under the $\underline{\mathrm{CC}-\mathrm{BY}-\mathrm{SA}}$ license.

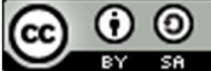




\section{PENDAHULUAN}

Indonesia sangat kaya dengan keragaman flora, namun dari sekian banyak yang diketahui, saat ini baru ada 8.000 jenis yang sudah teridentifikasi. Jumlah tersebut diperkirakan baru $20 \%$ dari jumlah flora yang ada di Indonesia (Utomo, 2011). Menurut Mittermeier, Myers, Mittermeier, dan Robles (1999) kekayaan jenis tumbuhan Indonesia diperkirakan 38.000 jenis atau menduduki peringkat ke-5 di dunia dengan tingkat endemisitas $\pm 55 \%$ tersebar di berbagai tipe ekosistem. Tanaman mempunyai mempunyai peran penting dalam kehidupan serta memberikan manfat dalam kehidupan sehari-hari. Tanaman memiliki karakteristik yang berbeda-beda. Oleh sebab itu, identifikasi sangat penting untuk mem-bantu manusia mengkategorikan fungsi dan manfaat tanaman tersebut. Banyak penelitian-penelitian sebelumnya yang membahas tentang jenis tanaman di Indonesia tetapi masih belum membahas tentang cara mengidentifikasinya. Untuk itu penelitian ini difokuskan pada penggunaan sebuah teknologi identifikasi tanaman dan mengetahui pengaruhnya terhadap orang yang menggunakannya. Bagi orang yang semula mengenal jenis tanaman tertentu, kemudian menemukan jenis tanaman yang belum diketahui sebelumnya dia akan kesulitan mengenali tanaman tersebut dikarenakan minimnya sumber pengetahuan tentang tanaman tersebut.

Pada materi IPA kelas VII kurikulum 2013 tentang klasifikasi makhluk hidup khususnya identifikasi tanaman, berdasarkan hasil observasi peneliti di lapangan, peserta didik kesulitan jika mengenal tanaman dengan hanya melihat buku teks saja. Mereka terkadang harus mencari dan bertanya kepada orang yang lebih tahu tentang wawasan tentang tanaman tersebut. Banyaknya kendala dalam mengidentifikasi tanaman, seperti kurangnya sumber belajar, penggunaan media pembelajaran yang kurang tepat, dan kurangnya wawasan pengetahuan akan identifikasi tanaman menjadi tujuan pembelajaran tidak tercapai, sehingga proses belajar mengajar menjadi kurang efektif. Peserta didik hanya disajikan gambar-gambar beserta penjelasan tanaman dalam buku yang jumlahnya masih terbatas, padahal di lingkungan sekitar kita banyak sekali jenis tanaman yang justru tidak semua disajikan dibuku bacaan tersebut. Proses belajar mengajar membutuhkan waktu yang lama, karena mereka harus mencari pengetahuan tentang tanaman tersebut dan bertanya kepada ahlinya. Minimnya sumber belajar yang kurang memadai, menjadikan mereka sulit memahami.

Dalam Peraturan Kementrian Pendidikan dan Kebudayaan Republik Indonesia Nomor 65 tahun 2013 tentang standart proses disebutkan bahwa proses pembelajaran menggunakan pendekatan atau metode pembelajaran yang sesuai dengan karakteristik peserta didik dan mata pelajaran. Oleh karena itu, dibutuhkan suatu pendekatan metode belajar yang dapat menjadikan mereka lebih memahami materi pembelajaran dan dengan tetap memperhatikan gaya belajar siswa agar mereka berkembang, baik berkembang secara afektif, kognitif, dan psikomotor. Memasuki zaman yang terus berubah dan berkembang seperti saat ini, proses pembelajaran memerlukan rancangan strategi dan media pembelajaran yang bervariatif untuk diterapkan kepada peserta didik sesuai dengan karakteristiknya.

Pengintegrasian pembelajaran secara kontekstual dengan teknologi dan memperhatikan gaya belajar siswa menjadikan proses belajar mengajar semakin mudah dan efektif. Untuk itu kita menggunakan aplikasi PlantNet dalam mengidentifikasi tanaman. Aplikasi PlantNet adalah sebuah aplikasi yang berguna untuk mengidentifikasi tanaman berdasarkan foto. Aplikasi ini dapat diunduh di Google Play Store untuk perangkat android dan iOS (iPhone Operating System). Cara kerjanya kita bisa hanya dengan memotret atau mengunggah foto dari ponsel kita. Setelah mengklik foto atau memuat foto, akan muncul fitur bagian tanaman, termasuk bunga, buah, daun, dan lain-lain yang akan kita identifikasi. Kemudian aplikasi memproses gambar dan konfirmasikan tanaman dari hasil aplikasi dengan tanaman yang kita identifikasi. Aplikasi PlantNet juga memiliki fitur feeds komunitas yang menunjukkan tanaman terbaru yang sudah diidentifikasi pengguna lain beserta gambar.

Berdasarkan uraian tersebut, maka penelitian ini mengkaji tentang: 1.) Pengaruh penggunaan aplikasi PlantNet terhadap hasil belajar IPA pada materi identifikasi tanaman siswa kelas $7 ; 2$.) Pengaruh gaya belajar siswa terhadap hasil belajar IPA pada materi identifikasi tanaman siswa kelas 7; dan 3.) Mengetahui interaksi antara penggunaan aplikasi PlantNet dan gaya belajar terhadap hasil belajar IPA siswa kelas 7. Dengan tujuan: 1.) Untuk mengetahui pengaruh penggunaan aplikasi

PlantNet terhadap hasil belajar IPA pada materi identifikasi tanaman siswa kelas 7; 2.) Mengetahui pengaruh gaya belajar siswa terhadap hasil belajar IPA pada materi identifikasi tanaman siswa kelas 
7; dan 3.) Mengetahui interaksi antara penggunaan aplikasi PlantNet dan gaya belajar terhadap hasil belajar IPA siswa kelas 7. Variabel penelitian ini terdiri dari variabel bebas yang berupa penggunaan aplikasi PlantNet, variabel moderator yang berupa gaya belajar siswa, dan variabel terikat yang berupa hasil belajar. Kelas eksperimen penelitian ini adalah penggunaan aplikasi PlantNet, sedangkan kelas kontrolnya tanpa aplikasi PlantNet dengan menggunakan diskusi kelas dalam mengidentifikasikan tanaman. Metode pembelajaran diskusi adalah suatu cara penyajian bahan pelajaran dengan langkah-langkah prosesnya, seorang guru memberi kesempatan kepada para siswa (kelompok-kelompok siswa) untuk mengadakan pembicaraan ilmiah guna mengumpulkan pendapat, membuat kesimpulan, atau menyusun berbagai alternatif pemecahan suatu masalah dengan demikian metode pembelajaran diskusi dapat dikatakan sebagai metode partisipatif dan juga termasuk metode kooperatif. Menurut Djumhur dan Surya (1975, p. 107) layanan bimbingan belajar dalam bentuk kelompok dalam bentuk diskusi kelompok adalah suatu cara atau teknik bimbingan yang melibatkan sekelompok orang dalam interaksi tatap muka, dimana dalam setiap anggota kelompok akan mendapat kesempatan untuk menyumbangkan pikiran masing-masing serta berbagi pengalaman atau informasi guna pemecahan masalah atau pengambilan keputusan dalam suatu permasalahan.

Perkembangan teknologi digital yang pesat dari segi dampak positif membawa banyak kemudahan bagi kita saat ini untuk menyelesaikan berbagai permasalahan yang muncul. Ada sebuah aplikasi yang membantu kita untuk mengetahui nama ilmiah, khususnya untuk tanaman. PlantNet, demikian nama aplikasi yang bisa kita download dari Google Play Store maupun Apple Store di smartphone kita. Sebuah aplikasi PlantNet ini pada dasarnya adalah sebuah mesin pencari gambar atau image search engine yang memungkinkan kita mengidentifikasi tanaman. Jika kita ingin tahu apa nama ilmiah dari satu tanaman, cukup dengan memasukkan gambar atau foto dari tanaman tersebut ke aplikasi PlantNet. Selanjutnya aplikasi tersebut akan memberikan informasi yang kita butuhkan. Mulai dengan memotret beberapa tanaman yang ada di sekitar tempat tinggal kita, dan kemudian kita akan menggunakan bantuan aplikasi PlantNet untuk menampilkan nama ilmiah tanamannya. PlantNet bisa memberikan informasi nama ilmiah dengan mencocokkan foto atau gambar dari bagian tumbuhan (daun, bunga, buah, dan batang). Ada dua cara yang bisa kita lakukan untuk memasukkan foto tanaman. Pertama dengan memotret terlebih dahulu tanaman tersebut dan kemudian memasukkan hasil foto tersebut ke aplikasi. Kedua adalah dengan cara sebaliknya yaitu membuka aplikasi terlebih dahulu lalu menekan tombol kamera yang ada dan memotret tanaman yang kita inginkan.

Dalam melaksanakan proses pembelajaran dengan penggunaan aplikasi PlantNet ataupun tanpa menggunakan aplikasi PlantNet, kita juga harus memperhatikan karakteristik gaya belajar siswa. Menurut Flemming dan Mills (1992), gaya belajar adalah kecenderungan siswa atau dominasi siswa untuk mengadaptasi strategi tertentu dalam belajarnya, sebagai bentuk tanggung jawabnya untuk mendapatkan satu pendekatan belajar yang sesuai dengan tuntutan belajar di dalam kelas/ sekolah maupun tuntutan dari mata pelajaran yang diberikan. Menurut Hamzah (2010) bahwa apapun gaya yang dipilih, perbedaan gaya belajar menunjukkan cara tercepat dan terbaik bagi setiap individu atau siswa untuk bisa menyerap sebuah informasi dari luar dirinya. Gaya belajar merupakan kondisi belajar internal. Gagne dan Briggs (1979) mengemukakan bahwa kondisi belajar internal mengacu kepada perolehan dan penyimpanan kapabilitas-kapabilitas yang telah dipelajari oleh peserta didik yang mendukung belajar kapabilitas lainnya.

Setelah mendapatkan perlakuan, maka selanjutnya diambil hasil belajar siswa melalui tahapan posttest pada lembar hasil pengamatan identifikasi tanaman. Hasil belajar yang dicapai siswa dipengaruhi oleh dua faktor yaitu yang berasal dari dalam diri siswa dan faktor dari luar diri siswa. Menurut Caroll (dalam Sudjana, 2009, p. 40) terdapat lima faktor yang mempengaruhi hasil belajar siswa antara lain: 1.) Bakat siswa; 2.) Waktu yang tersedia bagi siswa; 3.) Waktu yang diperlukan guru untuk menjelaskan materi atau pelajaran; 4.) Kualitas pengajaran; dan 5.) Kemampuan siswa. Menurut Munadi dalam Rusman (2013, p. 124) menyebutkan bahwa faktor-faktor yang mempengaruhi hasil belajar antara lain meliputi faktor internal dan faktor eksternal. Faktor utama yang mempengaruhi hasil belajar siswa antara lain: 1.) Faktor internal yakni keadaan atau kondisi jasmani dan rohani peserta didik; 2.) Faktor eksternal (faktor dari luar siswa), yakni kondisi lingkungan di sekitar peserta didik misalnya faktor lingkungan; dan 3.) Faktor pendekatan belajar, yakni jenis upaya 
kegiatan belajar siswa yang meliputi strategi dan metode yang digunakan untuk melakukan kegiatan mempelajari materi-materi pembelajaran.

Faktor yang mempengaruhi hasil belajar diantaranya faktor jasmani dan rohani siswa, hal ini berkaitan dengan masalah kesehatan siswa baik kondisi fisiknya secara umum, sedangkan faktor lingkungan juga sangat mempengaruhi. Menurut Hasan (1994) bahwa faktor-faktor yang mempengaruhi aktivitas belajar antara lain: 1.) Faktor yang terjadi pada diri organisme itu sendiri disebut dengan faktor individual adalah faktor kematangan/pertumbuhan, kecerdasan, latihan, moti-vasi dan faktor pribadi; dan 2.) Faktor yang ada diluar individu yang kita sebut dengan faktor sosial, faktor keluarga/ keadaan rumah tangga, guru dan cara mengajarnya, alat-alat yang digunakan atau media pengajaran yang digunakan dalam proses pembelajaran, lingkungan dan kesempatan yang tersedia dan motivasi sosial.

\section{METODE}

Penelitian ini merupakan penelitian eksperimen. Dilaksanakan pada tanggal 20 Januari 2020 sampai dengan tanggal 14 Maret 2020 di tiga tempat, yaitu SMP Negeri 2 Gedangan, SMP Negeri 3 Sidoarjo, dan SMP Negeri 4 Sidoarjo. Populasi dalam penelitian ini berjumlah 1.088 siswa kelas VII dari tiga sekolah tersebut. Teknik pengambilan sampel penelitian menggunakan teknik simple random sampling atau pengambilan sampel secara acak sederhana, yaitu dengan menggunakan nomor undian untuk memberikan kesempatan yang sama bagi setiap kelas menjadi sampel penelitian. Sampel kita ambil pada setiap sekolah masing-masing sejumlah 2 kelas untuk kelas eksperimen dan 2 kelas kontrol, sehingga total sampel sebanyak 6 kelas dengan rincian kelas eksperimen sebanyak 3 kelas dengan penggunaan aplikasi PlantNet, sedangkan kelas kontrol sebanyak 3 kelas dengan metode diskusi kelas.

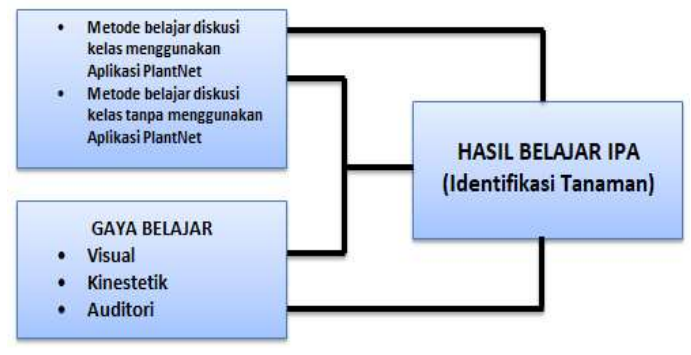

Gambar 1. Rancangan Desain Penelitian

Desain dalam penelitian ini adalah pengaruh penggunaan aplikasi PlantNet terhadap hasil belajar IPA, pengaruh gaya belajar terhadap hasil belajar IPA, dan interaksi antara penggunaan Aplikasi PlantNet dan gaya belajar terhadap hasil belajar IPA. Kelas eksperimen penggunaan aplikasi PlantNet sebanyak 104 siswa, dan kelas kontrol tanpa penggunaan aplikasi PlantNet, dengan menggunakan metode diskusi kelas sebanyak 101 siswa. Pengumpulan data gaya belajar pada penelitian ini menggunakan instrumen angket gaya belajar untuk mengetahui gaya belajar masingmasing siswa dan lembar kerja hasil pengamatan identifikasi tanaman untuk mengetahui hasil belajar siswa setelah mendapat perlakuan.

Instrumen angket gaya belajar menggunakan instrumen gaya belajar yang sudah tersedia dan dipakai berulang ulang pada artikel jurnal dengan tetap memperhatikan: 1.) Mengkaji variabel yang ditetapkan menjadi sub penelitian sejelas-jelasnya, sehingga indikator yang ditetapkan bisa diukur dan menghasilkan data yang diinginkan; 2.) Menentukan jenis instrumen yang telah ditetapkan; dan 3.) Menyusun kisi-kisi atau layout instrumen. Angket gaya belajar diukur apa adanya sesuai kondisi di lapangan. Hal ini sesuai dengan apa yang dipaparkan oleh Fatirul dan Walujo (2018) yaitu bahwa hubungan antara variabel dalam penelitian pembelajaran pada variabel moderator gaya belajar diukur apa adanya. Teknik analisis data menggunakan analisis varians (Anava) dua jalur dengan nilai 
signifikan sebesar $\alpha=0,05$. Penelitian ini melalui 3 tahapan, yaitu tahap persiapan, tahap pelaksanaan, dan tahap evaluasi.

Tahap Persiapan

Dalam tahap persiapan, peneliti melakukan pengamatan untuk mengetahui objek penelitian dengan pengambilan sampel secara simple random sampling/pengambilan sampel secara acak sederhana menggunakan nomor undian, yang kesemuanya berpeluang untuk menjadi sampel penelitian. Setelah sampel penelitian telah ditentukan kita menyiapkan Rencana Pelaksanaan Pembelajaran (RPP) untuk kelas eksperimen penggunaan aplikasi PlantNet maupun kelas kontrol tanpa menggunakan aplikasi PlantNet. Kemudian untuk mengetahui gaya belajar masing-masing siswa, seluruh sampel penelitian peneliti berikan angket gaya belajar yang kemudian harus diisi.

Tahap Pelaksanaan

Dalam tahap pelaksanaan kita membagi dalam dua kategori, yaitu kategori kelas eksperimen penggunaan aplikasi dan kelas kontrol tanpa menggunakan aplikasi PlantNet yaitu dengan menggunakan metode diskusi kelas. Untuk kelas penggunaan aplikasi PlantNet kita terlebih dahulu memberikan penjelasan cara penggunaan aplikasi PlantNet kemudian memastikan siswa untuk dapat menggunakannya. Setelah itu peneliti menentukan area untuk pengamatan identifikasi tanaman yang berada di sekitar halaman sekolah, siswa diminta mengidentifikasi tanaman yang berada di area sekitar halaman sekolah tersebut menggunakan aplikasi PlantNet. Kemudian siswa mencatat hasil identifikasinya di lembar hasil pengamatan identifikasi tanaman. Untuk kelas kontrol tanpa menggunakan aplikasi PlantNet, peneliti menjelaskan apa yang harus dilakukan siswa di area pengamatan yang sudah kita tentukan sebelumnya dengan area wilayah pengamatan yang sama dengan kelas eksperimen. Siswa diminta membentuk kelompok yang terdiri dari 5-6 anggota siswa untuk berdiskusi dalam mengidentifikasi tanamannya, kemudian mencatatnya dalam lembar hasil pengamatan identifikasi tanaman.

\section{Tahap Evaluasi}

Dalam tahap evaluasi, kelas eksperimen penggunaan aplikasi PlantNet maupun kelas kontrol tanpa penggunaan aplikasi yaitu dengan metode diskusi kelas, kita mengumpulkan nilai hasil belajarnya untuk mengetahui hasil belajar mereka setelah mendapatkan perlakuan. Data yang kita dapat dari hasil belajar dalam lembar hasil pengamatan identifikasi tanaman ini merupakan data terakhir yang kita olah dan kita gunakan untuk pembuktian hipotesis penelitian ini

\section{HASIL DAN PEMBAHASAN}

Hasil

Setelah melakukan observasi, melakukan eksperimen, pengumpulan data, dan dokumentasi selanjutnya data yang terkumpul dianalisis. Deskripsi data hasil penelitian setelah peneliti olah menggunakan analisis varians (Anava) dua jalur dapat dilihat pada Tabel 1.

Table 1. Distribusi Sampel Penelitian

\begin{tabular}{cccc}
\hline & \multicolumn{2}{c}{ Between-Subjects Factors } \\
& \multicolumn{2}{c}{ Value Label } & $\mathrm{N}$ \\
\hline \multirow{2}{*}{ Penerapan Aplikasi } & 1 & Aplikasi PlantNet & 104 \\
& 2 & Non Aplikasi/Diskusi Kelas & 101 \\
Gaya Belajar Siswa & 1 & Visual & 81 \\
& 2 & Auditori & 91 \\
& 3 & Kinestetik & 33 \\
\hline
\end{tabular}


Berdasarkan data pada Tabel 1 diketahui bahwa penggunaan aplikasi PlantNet berjumlah 104 siswa, sedangkan untuk kelas tanpa aplikasi PlantNet dengan menggunakan diskusi kelas berjumlah 101 siswa. Untuk jumlah gaya belajar visual sebanyak 81 siswa, gaya belajar auditori sebanyak 91 siswa, dan belajar kinestetik sebanyak 33 siswa.

Tabel 2. Descriptive Statistics

\begin{tabular}{ccccc}
\hline & \multicolumn{2}{c}{ Descriptive Statistics } & & \\
& Dependent Variable: Hasil Belajar IPA & & \\
Penerapan Aplikasi & Gaya Belajar Siswa & Mean & Std. Deviation & $\mathrm{N}$ \\
\hline \multirow{4}{*}{ Aplikasi PlantNet } & Visual & 98,21 & 3,346 & 42 \\
& Auditori & 98,89 & 2,102 & 45 \\
& Kinestetik & 97,71 & 3,901 & 17 \\
& Total & 98,42 & 2,984 & 104 \\
& Visual & 76,41 & 4,102 & 39 \\
& Auditori & 79,72 & 3,563 & 46 \\
& Kinestetik & 77,44 & 3,847 & 16 \\
& Total & 78,08 & 4,088 & 101 \\
& Visual & 87,72 & 11,572 & 81 \\
& Auditori & 89,20 & 10,070 & 91 \\
& Total & 87,88 & 10,971 & 33 \\
& Kinestetik & 88,40 & 10,800 & 205 \\
\hline
\end{tabular}

Berdasarkan pada Tabel 2 nilai rata-rata kelas eksperimen penggunaan aplikasi PlantNet dan gaya belajar visual terhadap hasil belajar IPA sebesar 98,21, sedangkan pada gaya belajar auditori terhadap hasil belajar IPA sebesar 98,89, serta gaya belajar kinestetik terhadap hasil belajar IPA sebesar 97,71. Total keseluruhan rata-rata nilai pada penerapan aplikasi PlantNet dan gaya belajar terhadap hasil belajar IPA adalah 98,42. Untuk nilai rata-rata kelas kontrol menggunakan diskusi kelas dan gaya belajar visual terhadap hasil belajar IPA sebesar 76,41, sedangkan pada gaya belajar auditori sebesar 79,72, serta gaya belajar kinestetik terhadap hasil belajar IPA sebesar 77,44. Total keseluruhan rata-rata nilai pada kelas kontrol tanpa aplikasi PlantNet atau penerapan diskusi kelas dan gaya belajar terhadap hasil belajar IPA adalah 78,08. Jadi total keseluruhan gaya belajar visual sebesar 87,72 dengan banyaknya 81 siswa. Total keseluruhan penggunaan aplikasi PlantNet maupun tanpa menggunakan aplikasi PlantNet gaya belajar visual sebesar 87,72 dengan jumlah 81 siswa, gaya belajar auditori sebesar 89,20 dengan jumlah 91 siswa, sedangkan kinestetik sebesar 87,88 dengan jumlah 33 siswa. Total jumlah siswa sebanyak 205 siswa rata-ratanya 88,40.

Tabel 3. Tests of Between - Subjects Effects

\begin{tabular}{|c|c|c|c|c|c|}
\hline \multicolumn{6}{|c|}{ Tests of Between-Subjects Effects } \\
\hline Source & $\begin{array}{c}\text { Type III Sum of } \\
\text { Squares }\end{array}$ & $d f$ & Mean Square & $F$ & Sig. \\
\hline Corrected Model & $21465,455^{\mathrm{a}}$ & 5 & 4293,091 & 366,703 &, 000 \\
\hline Intercept & 1300108,222 & 1 & 1300108,222 & 111051,451 &, 000 \\
\hline Penerapan & 17467,152 & 1 & 17467,152 & 1491,993 &, 000 \\
\hline Gaya & 187,186 & 2 & 93,593 & 7,994 &, 000 \\
\hline Penerapan * Gaya & 74,329 & 2 & 37,165 & 3,175 &, 044 \\
\hline Error & 2329,745 & 199 & 11,707 & & \\
\hline Total & 1625780,000 & 205 & & & \\
\hline Corrected Total & 23795,200 & 204 & & & \\
\hline a. $R$ Squared $=.90$ & ted $R$ Squared $=$ & & & & \\
\hline
\end{tabular}


Berdasarkan pada Tabel 3 diperoleh nilai signifikan sebesar 0,00 untuk penerapan aplikasi PlantNet maupun tanpa aplikasi PlantNet, sedangkan nilai signifikan pada gaya belajar diperoleh sebesar 0,000 , serta diperoleh nilai signifikan 0,044 untuk interaksi antara penerapan aplikasi PlantNet maupun tanpa aplikasi dengan gaya belajar terhadap hasil belajar siswa.

Pembahasan

\section{Pembahasan Hasil Pengujian Hipotesis Pertama}

Dalam pengujian hipotesis pertama, pengujian analisis penggunaan aplikasi diperoleh data 0,00. Dasar dalam pengambilan keputusan dalam uji Anava dua jalur yaitu:

Jika nilai signifikan $<0,05$, maka ada pengaruh hasil belajar berdasarkan variabel faktor. Jika nilai signifikan $>0,05$, maka tidak ada pengaruh hasil belajar berdasarkan variabel faktor.

Berdasarkan perhitungan yang dapat dilihat pada Tabel 3 diperoleh nilai signifikan penerapan atau penggunaan aplikasi PlantNet sebesar 0,000 , yang artinya ada pengaruh penerapan aplikasi PlantNet dan tanpa aplikasi PlantNet terhadap hasil belajar IPA kelas VII. Untuk penggunaan aplikasi PlantNet memiliki nilai rata-rata sebesar 98,270 dengan batas bawah sebesar 97,541 dan batas atas sebesar 98,998. Untuk penerapan diskusi kelas memiliki nilai rata-rata sebesar 77,855 dengan batas bawah sebesar 77,110 dan batas atas sebesar 78,601. Penggunaan aplikasi PlantNet memiliki nilai rata-rata lebih tinggi dibanding dengan penerapan diskusi kelas dalam hal materi identifikasi tanaman dengan perbandingan rata-rata sebesar 98,270 banding 77,855.

Perkembangan teknologi sekarang ini sangat maju dan tumbuh dengan pesat. Perkembangan ini tentu saja membawa pengaruh kepada berbagai sektor kehidupan manusia salah satunya adalah sektor pendidikan. Perkembangan teknologi terkini yang pesat adalah semakin seringnya penggunaan gadget khususnya smartphone dalam kehidupan sehari-hari, termasuk dibidang pendidikan. Hal ini membuka peluang besar dalam memanfaatkan teknologi aplikasi pada smartphone untuk dikembangkan menjadi media pembelajaran berbasis aplikasi (Setyawan \& Rufi'i, 2019) seperti yang peneliti lakukan pada kelas eksperimen penggunaan aplikasi PlantNet untuk mengidentifikasi tanaman. Dalam pembelajaran diperlukan inovasi-inovasi baru khususnya dalam pemanfaatan teknologi. Proses pembelajaran memanfaatkan perangkat elektronik sebagai alat bantu untuk mendukung dalam pembelajaran, sehingga proses pembelajaran menjadi lebih menarik, efektif, dan efisien (Warsihna, 2013) dengan kata lain, tujuan untuk melatih keterampilan penggunaan teknologi diintegrasikan kedalam aktivitas pembelajaran. Dalam beberapa penelitian, penggunaan aplikasi baik itu aplikasi apapun dalam pembelajaran memberikan pengaruh peningkatan hasil belajar, hal ini juga senada dengan hasil temuan pada penelitian yang dilakukan oleh Mulyani dan Wiwik (2018) pada penggunaan aplikasi berbasis android.

Aplikasi android dengan segala jenis aplikasinya memberikan berbagai macam aplikasiaplikasi yang bisa digunakan untuk mengatasi berbagai macam persoalan, misalkan aplikasi PlantNet untuk mengidentifikasi tanaman, aplikasi GPS (Global Positioning System), untuk mengetahui lokasi wilayah, dan masih banyak aplikasi penunjang lainnya. Penggunaan aplikasi yang berhubungan dengan pelajaran dalam proses belajar mengajar sangatlah penting baik bagi siswa maupun guru. Aplikasi terdiri dari tiga macam, yaitu aplikasi desktop, aplikasi website, dan aplikasi mobile. Aplikasi desktop yaitu aplikasi yang dijalankan pada perangkat PC atau laptop. Aplikasi website yaitu aplikasi yang dijalankan melalui webiste browser dan harus tersedia koneksi internet. Aplikasi mobile yaitu aplikasi yang dijalankan diperangkat mobile/smartphone dimana untuk kategori ini penggunaannya sudah banyak sekali.

Aplikasi PlantNet tergolong kedalam aplikasi mobile dan juga aplikasi website, namun penggunaannya lebih mudah pada mobile karena bisa dibawa kemana-mana dan praktis. Dalam situs Maxmanroe.com dijelaskan ada beberapa kriteria yang menandakan suatu aplikasi itu berkualitas dan memberikan manfaat pada penggunanya, yang pertama aplikasi dapat memenuhi kebutuhan user atau penggunanya. Kedua, aplikasi dapat berjalan di multi-platform, dan yang ketiga aplikasi dapat merespon instruksi dengan cepat, serta membutuhkan resource (processor, memory, storage) yang rendah. Aplikasi PlantNet merupakan aplikasi yang mempunyai kriteria sebagai aplikasi yang berkualitas. Aplikasi PlantNet dirancang khusus untuk membantu mengidentifikasi tanaman. Dalam 
penelitian ini siswa yang menggunakan aplikasi PlantNet lebih cepat memahami identifikasi tanaman dan memberikan nilai rata-rata sebesar 98,270. Untuk beberapa penelitian diskusi kelas dapat meningkatkan hasil belajar seperti penelitian yang dilakukan oleh Supriyati (2020), tetapi dibanding dengan penggunaan aplikasi PlantNet, diskusi kelas hanya memberikan nilai rata-rata sebesar 77,855 terhadap hasil belajar. Hal ini disebabkan karena kurangnya pengetahuan awal anggota dalam diskusi kelas terhadap pengenalan jenis tanaman dan kurangnya sumber belajar yang bisa dipakai sebagai rujukan atau acuan.

\section{Pembahasan Hasil Pengujian Hipotesis Kedua}

Pengujian hipotesis kedua membahas tentang pengaruh gaya belajar terhadap hasil belajar IPA siswa kelas VII. Gaya belajar yang diamati terdiri dari 3 jenis yaitu gaya belajar visual, auditori, dan kinestetik. Gaya belajar visual sebanyak 81 siswa, gaya belajar auditori sebanyak 91 siswa, dan gaya belajar kinestetik sebanyak 33 siswa. Dasar dalam pengambilan keputusan dalam uji Anava dua jalur yaitu:

Jika nilai signifikan $<0,05$, maka ada pengaruh gaya belajar berdasarkan variabel faktor.

Jika nilai signifikan $>0,05$, maka tidak ada pengaruh gaya belajar berdasarkan variabel faktor.

Berdasarkan hasil uji Anava dua jalur pada Tabel 3, diperoleh nilai signifikan gaya belajar sebesar $0,000<0,05$ yang artinya ada pengaruh gaya belajar terhadap hasil belajar IPA siswa kelas VII. Gaya belajar dipengaruhi oleh faktor alamiah atau pembawaan dan faktor lingkungan. De Porter dan Hernacki (2016) menyebutkan bahwa gaya belajar adalah kombinasi dari bagaimana siswa menyerap, lalu mengatur, dan mengolah informasi. Gaya belajar adalah cara siswa bereaksi dan menggunakan perangsang-perangsang yang diterimanya dalam proses belajar (Nasution, 2008). Gaya belajar adalah cara bagaimana seseorang menyerap, mengatur informasi kemudian mengolahnya serta memanifestasikan dalam wujud nyata perilaku hidupnya (Ula, 2013).

Terdapat karakteristik perbedaan masing-masing siswa dengan siswa yang lain berdasarkan gaya belajarnya. Siswa yang memiliki gaya belajar visual, cenderung banyak menggunakan penglihatannya untuk melakukan proses belajar mengajarnya. Mereka lebih memahami suatu pembelajaran ketika diperlihatkan melalui gambar-gambar atau benda konkretnya. Mereka akan kesulitan jika proses pembelajaran dikemas sedikit gambar atau sedikit menunjukkan benda nyata, karena kekuatan cara belajar mereka lebih dominan pada hal visual. Dalam penelitian ini siswa yang memiliki gaya belajar visual sebanyak 81 siswa memiliki nilai rata-rata sebesar 87,72. Kendala dari mereka yang memiliki gaya belajar visual adalah mereka akan mudah terganggu jika ia terlalu banyak mendengarkan suara-suara bising dari temannya ketika proses belajar mengajar sedang berlangsung dan juga sulit untuk mengikuti instruksi secara lisan dan sering salah menginterpretasikan kata atau ucapan (Tanta \& Langton, 2010).

Kelebihan gaya belajar visual adalah mereka sangat antusias dan mudah memahami jika mereka harus belajar secara langsung melihat untuk mengidentifikasi tanaman. Baik kendala maupun kelebihan pada siswa yang memiliki gaya belajar visual terjadi di kelas eksperimen maupun kelas kontrol. Siswa yang memiliki gaya belajar visual di kelas ekperimen penggunaan aplikasi PlantNet memiliki rata-rata 98,21, sedangkan di kelas kontrol penggunaan diskusi kelas memiliki rata-rata nilai sebesar 76,41 lebih kecil dari kelas eksperimen. Hal ini terjadi karena didalam penggunaan aplikasi PlantNet proses pembelajarannya sangat mengakomodir gaya belajar visual, mereka mengidentifikasi tanaman dengan melihat secara langsung. Tetapi untuk di kelas kontrol penggunaan kelas mereka melihat langsung tetapi banyak didominasi oleh kegiatan diskusi-diskusi. Hal inilah yang membuat besaran nilai rata-rata di penggunaan aplikasi PlantNet lebih tinggi dibanding diskusi kelas. Hasil penelitian ini sesuai dengan yang dilakukan oleh Nurmayani \& Syuaib (2016) yang menyatakan ada pengaruh gaya belajar terhadap hasil belajar. Untuk siswa yang memiliki gaya belajar auditori sebanyak 91 siswa dengan perolehan nilai rata-rata sebesar 89,20.

Pada kelas eksperimen penggunaan aplikasi PlantNet memperoleh nilai rata-rata sebesar 98,89, dan pada kelas kontrol penerapan diskusi kelas nilai rata-rata sebesar 79,72. Siswa yang memiliki gaya belajar auditori cenderung menggunakan indera pendengarannya dalam proses pembelajaran. Kemampuan guru untuk mengemas pembelajaran yang sesuai dengan gaya belajar ini sangat diperlukan agar mereka lebih mudah dalam memahami materi yang diberikan. Data nilai rata- 
rata kelas eksperimen penggunaan aplikasi PlantNet lebih tinggi dibandingkan dengan kelas kelas kontrol penerapan diskusi kelas. Hal ini terjadi karena faktor kemampuan guru mengemas pembelajaran penggunaan aplikasi PlantNet juga mengakomodir karakteristik gaya belajar auditori, guru memberikan instruksi-instruksi melalui suara dengan jelas dan memberikan penekananpenekanan materi melalui suara. Kesulitan dalam gaya belajar auditori ini siswa sulit memahami atau menyerap informasi dalam bentuk gambar-gambar atau benda konkretnya jika siswa tidak ditambahkan dengan penjelasan melalui suara.

Untuk siswa yang memiliki gaya belajar kinestetik dalam penelitian ini sebanyak 87,88 dengan jumlah siswa sebanyak 33. Perolehan nilai rata-rata dalam kelas eksperimen penggunaan aplikasi PlantNet sebesar 97,71, sedangkan perolehan nilai rata-rata dalam kelas kontrol penerapan diskusi kelas sebesar 77,44. Hal ini menunjukkan bahwa gaya belajar kinestetik dipenggunaan aplikasi PlantNet lebih tinggi dibanding dengan penerapan diskusi kelas. Hal ini terjadi karena dalam proses penggunaan aplikasi PlantNet siswa yang memiliki gaya belajar kinestetik sangat terakomodir. Gaya belajar kinestetik lebih melibatkan gerakan. Siswa bertipe ini lebih mudah memahami sesuatu dengan mempraktekkannya. Tipe ini menitikberatkan pada pengalaman langsung dengan obyek yang dipelajari. Selain itu, siswa dengan gaya belajar kinestetik juga lebih mudah mengingat setelah mereka menyentuh obyek dan memperagakannya sendiri, karena pada siswa dengan gaya belajar kinestetik mempelajari sesuatu akan lebih mudah jika tidak hanya sekedar membaca atau mendengarkan penjelasan, tapi dengan terjun langsung ke lapangan untuk memahami dan mengingat sendiri tempat atau obyeknya.

Dengan melihat data perolehan nilai rata-rata dan uraian gaya belajar tersebut, dapat disimpulkan bahwa gaya belajar (visual, auditori, dan kinestetik) berpengaruh terhadap hasil belajar IPA. Hasil penelitian ini sesuai dengan penelitian yang dilakukan oleh Candra, Indrawan Dwi (2015) yang menyimpulkan adanya pengaruh gaya belajar terhadap hasil belajar. Dalam penelitiannya gaya belajar memberikan pengaruh sebesar $11,8 \%$ terhadap hasil belajar siswa pada kelas IV SD Negeri Pajang 3 Surakarta yang dilakukan pada tahun ajaran 2014/2015. Hal ini juga senada dengan penelitian yang dilakukan oleh Iriani dan Leni (2013) yang menyimpulkan dalam penelitiannya terdapat pengaruh yang signifikan terhadap hasil belajar pada mata pelajaran matematika siswa kelas VIII SMP Negeri 2 Kerinci. Penelitian ini juga sesuai dengan yang dilakukan Degeng dan Degeng (2018) yang menyimpulkan ada pengaruh positif dan signifikan gaya belajar terhadap hasil belajar siswa dengan nilai $\mathrm{R} 66,0 \%$

\section{Pembahasan Hasil Pengujian Hipotesis Ketiga}

Pembahasan uji hipotesis yang ketiga adalah pengujian interaksi antara penggunaan aplikasi PlantNet dan gaya belajar terhadap hasil belajar IPA siswa kelas VII. Dasar dalam pengambilan keputusan dalam uji Anava dua jalur yaitu:

Jika nilai signifikan $<0,05$, maka ada pengaruh interaksi berdasarkan variabel faktor.

Jika nilai signifikan $>0,05$, maka tidak ada pengaruh interaksi berdasarkan variabel faktor.

Berdasarkan hasil uji Anava dua jalur diperoleh nilai signifikansi penerapan aplikasi dan gaya belajar sebesar $0,044<0,05$ yang artinya terdapat interaksi antara penerapan aplikasi PlantNet dan gaya belajar terhadap hasil belajar IPA siswa kelas VII. Penelitian ini menemukan adanya interaksi antara penggunaan aplikasi PlantNet versus diskusi kelas dan gaya belajar terhadap hasil belajar IPA siswa kelas VII. Pada kelas eksperimen penggunaan aplikasi PlantNet diperoleh nilai rata-rata sebesar 98,270 dengan batas bawah sebesar 97,541 dan batas atas sebesar 98,998. Hasil nilai rata-rata ini berbeda pada kelas kontrol yang menggunakan penerapan diskusi kelas yang memperoleh nilai rata-rata sebesar 77,855 dengan batas bawah sebesar 77,110 dan batas atas sebesar 78,601 . Hal ini menunjukkan bahwa kelas eksperimen penggunaan aplikasi PlantNet memberikan pengaruh lebih tinggi dibandingkan dengan kelas kontrol penerapan diskusi kelas.

Ada suatu pengaruh dan perbedaan hasil belajar IPA dilihat dari perolehan hasil nilai rataratanya. Pengaruh interaksi ini juga terlihat pada data gaya belajar visual sebesar 98,214 , gaya belajar auditori sebesar 98,889, dan gaya belajar kinestetik sebesar 97,706 untuk kelas eksperimen penggunaan aplikasi PlantNet. Hal ini sangat berbeda hasilnya pada gaya belajar (visual, auditori, kinestetik) untuk kelas kontrol penerapan diskusi kelas. Pada kelas kontrol gaya belajar visual 
memperoleh nilai rata-rata sebesar 76,410 , gaya belajar auditori sebesar 79,717 , dan gaya kinestetik sebesar 77, 438, sehingga gaya belajar (visual, auditori, kinestetik) diterapkan penggunaan aplikasi PlantNet memberikan nilai lebih tinggi dibandingkan gaya belajar (visual, auditori, kinestetik) pada penerapan diskusi kelas. Temuan penelitian ini senada dengan penelitian yang dilakukan oleh Primartadi (2012) yang menyimpulkan dalam penelitiannya bahwa pada metode STAD dan PBL terdapat interaksi antara metode pembelajaran yang diterapkannya dengan potensi akademik siswa dan pengaruhnya terhadap pencapaian hasil belajar dengan perolehan nilainya pada potensi akademik tinggi untuk metode STAD yaitu sebesar sebesar 7,73 dan perolehan metode PBL pada potensi akademik tinggi yaitu sebesar 8,15 .

\section{SIMPULAN}

Berdasarkan hasil analisis data pengujian hipotesis dan pembahasan penelitian hasil belajar siswa maka dapat disimpulkan sebagai berikut: 1.) Terdapat pengaruh penggunaan aplikasi PlantNet maupun tanpa menggunakan aplikasi PlantNet terhadap hasil belajar IPA tentang materi identifikasi tanaman; 2.) Terdapat pengaruh gaya belajar terhadap hasil belajar IPA tentang materi identifikasi tanaman; dan 3.) Terdapat interaksi antara penggunaan aplikasi PlantNet dan gaya belajar siswa terhadap hasil belajar IPA tentang materi identifikasi tanaman.

\section{DAFTAR PUSTAKA}

De Poter, B. \& Hernacki, M. (1999). Quantum learning. Bandung: Penerbit Kaifa.

Degeng, I. N. S., \& Degeng, P. D. D. (2018). Ilmu pembelajaran klasifikasi variabel untuk pengembangan teori dan penelitian. Yogyakarta: Yayasan Taman Pustaka Kristen Indonesia.

Djumhur, I., \& Surya, M. (1975). Bimbingan dan penyuluhan di sekolah. Bandung: CV Ilmu.

Fatirul, N. A., \& Walujo, A. D. (2018). Metode penelitian dan pengembangan. Surabaya: Jakad Publishing.

Flemming, N. D., \& Mills, C. (1992). Not another inventory, rather a catalyst for reflection. To Improve The Academy, 11(1), 137-155. doi:https://doi.org/10.1002/j.2334$\underline{\text { 4822.1992.tb00213.x }}$

Gagne, R. M., \& Briggs, L. J., (1979). Principles of instructional design. New York: Holt, Rinehart and Winston.

Hamzah, D. U. (2010). Orientasi baru dalam psikologi siswa yang memiliki gaya belajar. Jakarta: Bumi Aksara.

Hasan, C. (1994). Dimensi-dimensi psikologi pendidikan. Surabaya: Al Ikhlas.

Iriani, D., \& Leni, M. (2013). Identifikasi gaya belajar dan pengaruhnya terhadap hasi belajar siswa pada materi kubus dan balok di kelas VIII SMPN 2 Kerinci. Prosiding SEMIRATA 2013, $1(1), 109-114$.

Mittermeier, R. A., Myers, N., Mittermeier, C. G., \& Robles Gil, P. (1999). Hotspots: Earth's biologically richest and most endangered terrestrial ecoregions. CEMEX, SA, Agrupación Sierra Madre, SC.

Nasution, S. (2008). Berbagai pendekatan dalam proses belajar mengajar. Bumi Aksara: Bandung

Nurmayani, N., \& Syuaib, M. Z. (2017). Pengaruh gaya belajar VAK pada penerapan model pembelajaran problem based learning terhadap hasil belajar IPA fisika siswa SMP Negeri 2 Narmada tahun ajaran 2015/2016. Jurnal Pendidikan Fisika dan Teknologi, 2(1), 13-21. doi: https://doi.org/10.29303/jpft.v2i1.283 
Kementrian Pendidikan dan Kebudayaan Republik Indonesia. (2013). Peraturan Kementrian Pendidikan dan Kebudayaan Republing Indonesia Nomor 65 Tahun 2013 tentang Standard Proses Pendidikan Dasar dan Menengah.

Primartadi, A. (2012). Pengaruh metode Student Teams-Achievement Division (STAD) dan problem based learning terhadap hasil belajar ditinjau dari potensi akademik siswa SMK otomotif. Jurnal Pendidikan Vokasi, 2(2), 143-153. doi:https://doi.org/10.21831/jpv.v2i2.1024

Rusman, R. (2013). Faktor-faktor yang mempengaruhi hasil belajar. Jakarta: Bumi Aksara.

Setyawan, B., \& Rufi'i, A. N. F. (2019). Augmented Reality dalam pembelajaran IPA bagi siswa SD. Kwangsan: Jurnal Teknologi Pendidikan, 7(1), 78-90. doi:https://doi.org/10.31800/jtp.kw.v7n1.p78--90

Sudjana, N. (2009). Penilaian hasil proses belajar mengajar. Bandung: PT. Rosdakarya.

Supriyati, I. (2020). Penerapan metode diskusi dalam pembelajaran keterampilan berbicara pada siswa kelas VIII MTS Negeri 4 PALU. Jurnal Bahasa dan Sastra, 5(1).

Mulyani, S., \& Wiwik, E. (2018). Dampak pemanfaatan aplikasi android dalam pembelajaran bangun ruang. Kwangsan: Jurnal Teknologi Pendidikan, 6(2), 122-136. doi: https://doi.org/10.31800/jtp.kw.v6n2.p122--136

Tanta, K. J., \& Langton, S. Y. (2010). NICU primer for occupational therapists: Exploring the needs of fragile infants, the context in which they are cared for, and the role of OT in this specialized practice area - part I of II. Journal of Occupational Therapy, Schools, \& Early Intervention, 3(2), 179-186. doi:https://doi.org/10.1080/19411243.2010.491020

Ula, S. S. (2013). Revolusi belajar: Optimalisasi kecerdasan melalui pembelajaran berbasis kecerdasan majemuk. Yogyakarta: Ar-Ruzz Media.

Utomo, Y. W. (2011, December 2019). Baru 20 persen Flora yang Teridentifikasi. Retrieved from https://sains.kompas.com/read/2011/11/30/18112181/Baru.20.Persen.Flora.yang.Teridentif ikasi.

Warsihna, J. (2013). E-learning melalui portal rumah belajar. Jurnal Teknodik, 73-84. doi: http://dx.doi.org/10.32550/teknodik.v0i0.9 